\title{
Student-Produced Videos Can Enhance Engagement and Learning in the Online Environment
}

\author{
Denise Stanley and Yi Zhang \\ Mihaylo College of Business and Economics, California State University, Fullerton
}

\begin{abstract}
Student engagement in online learning remains a challenge for the design of effective coursework. Additionally, few analyses have focused on student-produced activities in the online mode or upon how such class activity affects student subgroups differently. We conducted a randomized design experiment with student video production at a large public university. Student background and behavior factors were measured in two online surveys, which were combined with course assessment data. Because of the small sample size, we observed few significant differences in learning outcomes across the experimental treatment and control sections, except with regard to a value-added measure. We suggest that student learning was likely most concentrated on concepts around which students produced the videos. And when students were divided by incoming language proficiency, non-native English speakers had higher perceived learning; but when grouped by incoming GPA, those with higher previous grades actually achieved higher test scores and pass rates.
\end{abstract}

Keywords: student-generated videos, peer learning, demographic factors, random design

Stanley, D., \& Zhang, Y. (2018). Student-produced videos can enhance engagement and learning in the online environment. Online Learning, 22(2), 5-26. doi: 10.24059/olj.v22i2.1367

\section{Student-Produced Videos Can Enhance Engagement and Learning in the Online Environment}

Online education offers opportunities to enhance student success particularly when it (1) allows universities to increase class offerings if space constrains the number of classroom sections, (2) brings education access to students who cannot come to campus to take classes, and (3) enhances the performance of subgroups of student learners who engage better in a digital environment (Betts, Hartman, \& Oxholm, 2009; Clark, 2009; Lorenzo \& Moore, 2002). Although learning outcomes usually exhibit no statistical difference across modes, research and observations in cross-disciplinary venues (i.e., The Chronicle of Higher Education, The American Journal of Distance Education) mention the higher dropout rates of students taking an online version of coursework compared to a traditional lecture section. One reason for this could be lower student engagement in online-classes compared to face-to-face classes. Another possible issue is how students with different demographic backgrounds react to an online class. 
Designing effective pedagogies within online coursework, thus, must involve enhancing student engagement and satisfaction. For example, collaborative learning and enhanced social presence (joint participation in interactions) build community in asynchronous learning networks and, as a result, increase student engagement in online classes (Rovai, 2000). Chang and Smith (2008) find higher levels of student-student interaction (through chat sessions, discussion boards, and other projects) to be a significant predictor of satisfaction; Dixson (2010) links these interaction factors to student course engagement. Activities in which students make presentations and teach each other are effective practices highlighted in the National Survey of Student Engagement (NSEE, 2010).

Personal and demographic characteristics may affect students' learning in the online environment. The impact of student computer self-efficacy, prior online experience, and feelings regarding online course delivery appears mixed (Puzziferro, 2008; Jan, 2015). Bolliger, Supanakorn, and Boggs (2010) suggest that background factors (e.g., gender and online experience) affect student motivation, preferences, and ultimately satisfaction with pedagogies such as podcasts; Hargittai (2010) uses regression analysis to find that gender and race are significant predictors of higher levels of Web-use skills and the access necessary to succeed in an online class. Zhang (2015) finds that students of higher socioeconomic status are more likely to utilize some learning technologies (e.g., Khan Academy). There is not much research examining how demographic background impacts different stages of online learning, such as preparedness, class behavior, learning outcome, and satisfaction.

Multimedia design components generally involve an audio or video file of content placed online for course material delivery. Faculty- or professional-generated multimedia components are common for online or hybrid course design. Most research on faculty-generated multimedia components in online courses shows that it leads to positive results in actual and perceived student learning (see Kay, 2012, for a review). An exception is Dupange, Millette, and Grinfeder (2009), who found that a (nonrandomly selected) group of students viewing videos did worse than nonviewers in a communication studies course; additionally, the viewing levels were lower for nonwhite students and higher for those expressing positive attitudes toward online education and computer literacy. A Dupuis, Coutu, and Laneuville (2013) study finds that lower GPA students demonstrated the largest gains in test scores after watching the videos and that the learning gains were concentrated around particular exams/concepts.

The innovation of student-generated course material represents a novel recent addition to online courses (Guertin, 2010; Bolliger et al., 2010; Kay, 2012). In general, this effort builds upon the use of student discussion forum activities in the online class mode to enhance interaction and cognitive engagement (see for example Zhu, 2006). Multimedia moves the interaction to a more visual and auditory presentation of the discipline concepts. Students producing podcasts gain not only subject knowledge but also professional presentation skills, while the broader group gains peer learning through these student-generated videos.

The literature has documented student-generated multimedia activities primarily in the science and business disciplines. Surveys show different positive impacts (teamwork, communication, satisfaction) of podcasting in engineering (Alpay \& Gulati, 2010), information technology (Bolliger \& Armier, 2013), and geography (Anderson, 2013). Student responses indicate increased perceived learning in a variety of business disciplines (Armstrong, Tucker, \& Massad, 2009; Alon \& Herath, 2014; Orus et al., 2016). And nursing students exhibit greater 
development of core competencies in sections with self- and peer-recorded videos, compared to traditional lecture classes (Pereria, Echeazarra, Santamaria, \& Gutierrez, 2014).

Moryl (2013) summarized an assignment in which viewing of professionally produced podcasts increased perceptions of economic understanding. Later, Moryl (2016) documented how student groups created their own YouTube videos of economic concept presentations. Our project differs from Moryl $(2013,2016)$ in that we focus on upper division economics coursework and individual efforts. We include a somewhat larger random sample and analyze the effects of student video production on both satisfaction, motivation and actual quantitative learning achievement.

Our particular strategy represents an example of active learning and student peer provision of learner support and feedback, which could influence student success directly and/or indirectly through its contribution to student course engagement and satisfaction. Yet it is a component that requires some technical skills, fluency in English, and comfort with public presentations. So analysis of student background characteristics and their possible interplay with the component can shed light on the observed actual learning outcomes. In the analysis below, we focus on differences in preparation, behavior, and outcomes not only by treatment status but also by previous academic performance (GPA), gender, underrepresented status (e.g., Hispanic), Pell Grant status, whether English is the student's first language, and mother's educational attainment.

We examined whether differences exist among students along demographic background and whether these differences correlate to differences in terms of their readiness for online education, behavior in the class, and performance. We discuss a student-generated video project to increase student learning and retention in online education. Ideally, it could promote student engagement with course content, and provide supplemental learning materials for the class, which could benefit particular groups of students desiring more visual tools. The following were our two research questions:

1. Does the student-generated video component increase student engagement with the class and improve learning outcomes?

2. Are there any differences among groups of students with varied demographic backgrounds in terms of online education readiness, engagement in the online environment, and/or learning outcomes and satisfaction in online classes?

To answer these questions, we implemented a random experimental design in spring 2016 with two online class sections of the same course, with one using the self-generated video component and the other not using it.

\section{Participants}

\section{Methods}

This study used an experimental design based on the random assignment of 113 everenrolled students across two online sections of a managerial economics class. Randomization occurred 72 hours before the first day of the spring 2016 semester. This course is required for all students who want to get a BA in Business Administration. Students enrolled in the class are either at the junior or senior level. The random design reduced possible biases from the correlation between unobservable factors, student behavior, and the outcome variables by providing exogenous variation in treatment. Sample selection bias could occur if, when students chose to participate in a class with oral presentations, hidden characteristics behind their likelihood to 
participate also affected test scores. Students were assigned to each class section using an Excel random number generator, with verification of the comparability of the samples based upon their incoming academic qualifications (see Appendix A). Some students dropped the class (with three late adds) during the first two weeks of the class before the video activity began. Ultimately, 97 students remained enrolled in the class and received surveys; 87 took the final exam. The first survey had 84 respondents (an 87\% response rate) and the second survey 78 respondents (an $80 \%$ response rate) across both sections. Response rates were encouraged by extra credit incentives.

\section{Student Background}

In general, data from the first survey suggests students were somewhat older (average 25 years $[S D=4.91])$ and worked more than 24 hours/week $(S D=16.60)$. There were slightly more women $(41 \%$ men, $S D=0.50)$. Most of the students had lower income levels $(71 \%$ Pell Grant eligible, $S D=0.46$ ) and definite past experience (average 5.05 courses, $S D=3.84$ ) in online education. They had diverse ethnic backgrounds (33\% Hispanic, the rest reported as non-Hispanic and primarily as Asian or Caucasian) and moderate incoming grades (mean incoming GPA $=2.91$, $S D=0.40)$. Almost half of the students' mothers did not complete college $(S D=0.50)$. Seventynine percent of the students also reported English as their primary language $(S D=0.41)$. These characteristics were similar across class sections, except that survey results showed that students in the treatment sections could be coming in with somewhat better English skills, while those in the control group were more likely to self-identify as Hispanic. There were no significant differences across the treatment/control groups with regard to work hours or previous online experience, although students with Pell Grants (financial aid) tended to have fewer work hours than those without the grants. There was some overlap between the students in our six background categories; for instance, there was a significant positive correlation between male gender and Hispanic ethnicity and between English being the native language and a mother's completing college. Very few physical or otherwise disabled students enrolled in the classes, with no differences across sections.

\section{Measures}

In this study, we included measures on demographics, students' perception of their preparation for online classes, their perception of the class, and actual performance data. Demographic information was collected through the Office of Institutional Research, and students' perceptions were measured through Likert-scale survey questions drawn from the DETA Research Toolkit 1.0 (Joosten \& Reddy, 2015). Actual performance was measured through students' grades on various online activities (on the Moodle and McGraw-Hill Connect websites). Variable definitions are provided in Appendix B. Characteristics of survey items were developed after consultation with experts, a literature review of key instruments, and expert-developed classifications to group items (see Joosten \& Reddy, 2015). The first survey included 22 variables from the Toolkit related to background personal and academic characteristics as well as six variables linked to student preparedness and readiness for the course. Among the demographic/academic background variables, incoming GPA and native English language ability could give students an advantage in class performance, as would the reality of fewer work hours and greater previous online course completion. In the analysis below, we focus on six binary dimensions by which the student population can be characterized: low versus high incoming GPA, gender, Hispanic versus non-Hispanic, Pell Grant status, native English language, and mother's college completion versus noncompletion. Within each dimension, the population is divided into two subgroups. 
The first survey included the preparedness and readiness questions (measures of experience in distance education, access to technology, online skills proficiency, technology familiarity, online learning efficacy, and self-directedness). These factors could be relevant to how the class activity affects the outcomes of each student. For instance, a student with greater computer selfefficacy could produce a better quality video more efficiently, thereby impacting their own and peer outcomes.

The second survey focused on student behavior and perceptions at the end of the course. Students were asked about their perceived course activity challenge, course interactivity, and active learning behaviors in the course, as well as their perceptions of the course social presence and engagement. The second survey also included questions on student outcomes, including scalar and open-ended queries regarding how student performance, learning, satisfaction, and success were impacted by the course.

Among the measures in the questionnaires, we found that the following six variables (Table 1) were most relevant to this study and provided the most internal consistency as measured through Cronbach's alpha.

\section{Table 1.}

Initial Survey Background Response-Item Consistency

\begin{tabular}{|l|l|l|}
\hline Variable group & Cronbach's alpha statistic & Items \\
\hline PRESKILLS (1-7) Online Skill Proficiency & .972 & 7 \\
\hline PRESE (1-6) Online Learning Efficacy & .861 & 6 \\
\hline PRESD (1-4) Self-directedness & .914 & 4 \\
\hline ENGAGE (4-8, 10, 12-15) Engagement & .965 & 10 \\
\hline LEARN (1, 3-8) Perception of Learning & .973 & 6 \\
\hline PERFORM (1-5) Perception of Performance & .868 & 5 \\
\hline
\end{tabular}

Since these questions were on a Likert scale $(1=$ strongly disagree, $2=$ disagree, $3=$ neutral, 4 =agree, 5 = strongly agree), a higher number represents a more favorable response. For the purposes of this research, where we want to look at differences among subgroups, we first calculated a total score for each student for each variable area in Table 1. We then determined an average score (between 1 and 5) for each student. The questions (listed in Appendix B) meant that a higher number on the Likert scale implied a student felt they had a greater degree of online skill proficiency, efficacy, or self-directedness. At the end of the class, a student choosing agree or strongly agree would be indicating more engagement and a higher perception of learning and performance in the class.

Other variables measured by the instructor included student performance on module online homework and quiz activities, as well as treatment student scores on the video activity and ratings for each module. The online textbook-homework bundle provided access to a class-specific website for the graded problem sets and the optional Learn Smart concept mastery exercises. (This publisher's website also tracks student engagement through time, frequency, and success of activities.) The final exam provided the primary learning assessment measures (correct multiplechoice question numbers and points, worked problem scores) and the value- added score. This 
score included 10 questions administered as a pretest (before students opened the content website) and as a posttest, with those same questions incorporated within the final exam. The content of the 10 questions included key concepts from across the coursework: marginal analysis, the value of a firm, linear demand function interpretation, own-price elasticity, cost measures, principal-agent concerns, market structure measures, monopoly profit maximization, oligopoly game-theory analysis, and second-degree price discrimination.

\section{Procedures}

Both the treatment and control student groups had unique Moodle websites with common study activities (online lecture content and quizzes), and common exams were administered online or on campus at separate locations. The two groups were also placed in two separate McGraw-Hill homework websites. The same final exam for both sections was $30 \%$ of the class grade. The online student-generated problem-solving video project comprised $10 \%$ of the grade in the treatment sections, with the other activities (quizzes, homework) scaled for comparability (i.e., in the treatment group, each homework earned up to 10 points and each quiz up to 5 points; in the control group, each homework earned up to 15 points and each quiz up to 7.5 points, so the points in the treatment were multiplied by 1.5).

Each student in the treatment section was asked to produce a narrated video showing the steps to solve a typical exam multiple-choice problem. Students were given a window in which to choose the topic; after that, the instructor assigned problems randomly. Students were provided a guideline sheet outlining the options (a narrated PowerPoint slideshow, a YouTube video, etc.) and examples created by the instructor and the publisher. Sample topics presented in the student videos included (a) the steps to calculate full economic price under a price ceiling, (b) the steps to calculate own-price elasticity from a linear demand function, and (c) the steps to calculate the optimal two-part pricing scheme for a firm with market power. Each student created a video and posted it in a discussion forum link by Thursday of the relevant module. Other students viewed it and provided ratings and comments in the forum. Each student earned up to 25 points $(5 \%$ of the class grade) for the video produced and up to 5 points for each of five ratings of other students' videos (viewing of additional videos was encouraged and open throughout the semester). Assignment grading was based upon a rubric providing $60 \%$ of the weight for video content, $20 \%$ for how other students rated the video, and $20 \%$ for the video's technical quality to encourage serious efforts at peer teaching.

\section{Data Analysis}

In the outcomes below, we employ a mixed methods approach to data analysis. We use quantitative tools (cross-tabulations, $t$-tests, $F$-tests, and ANOVA) to analyze the data trends in survey and instructional data across the treatment and control groups, as well as within demographic subgroups. We also include qualitative comments to provide context to the trends observed. All calculations were undertaken in SPSS-24.

\section{Results}

\section{Differences in Students' Perception of Their Online Readiness}

First, we examine the subgroup differences in terms of students' perceptions of their skills and readiness for the online class. Table 2 shows the overall section average values for each of the response question areas with standard deviations in parentheses. In no case was the summary index 
significantly different across the randomly sorted treatment and control sections. Most students felt they possessed strong skills and self-directedness for online coursework. Yet very few believed strongly in the efficacy of online coursework. Most students answered strongly agree or agree on the Likert-scale questions $(4,5)$ on the preparedness and readiness questions included in the first survey. A few significant variations appear across the focus subgroups with regard to the average responses on specific frequency-based questions (PREPSKILLS). (See Appendix B for specific question wording.) Table 2 shows that women (particularly in the treatment section) and non-Pell Grant students had significantly stronger beliefs about the efficacy of online courses (differences in bold). Nearly all students had taken several online courses in the past.

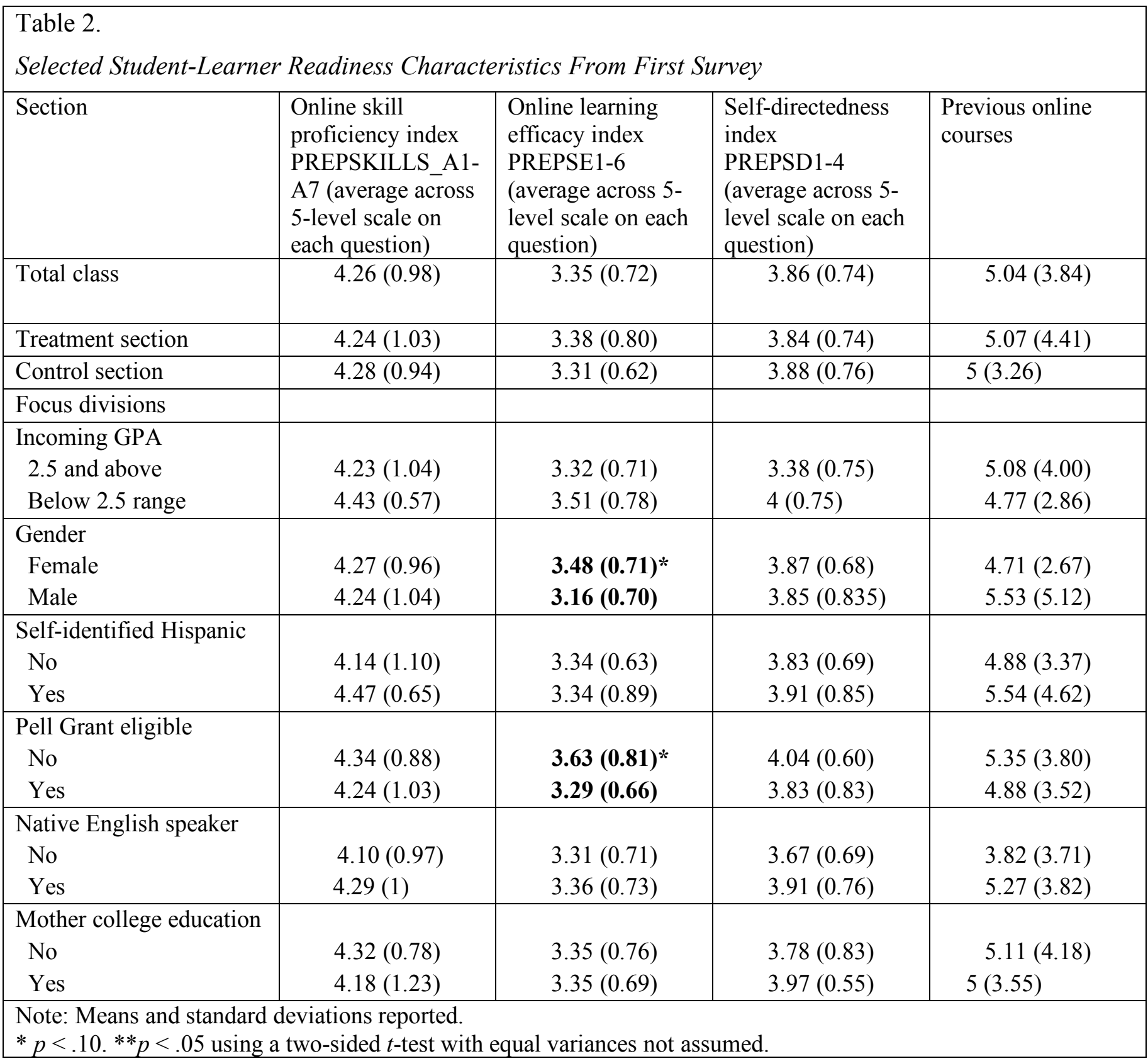




\begin{tabular}{|c|c|c|c|c|c|}
\hline & $\begin{array}{l}\text { McGraw-Hill } \\
\text { Engagement } \\
\text { Index*** } \\
(0-10)\end{array}$ & $\begin{array}{l}\text { Survey Engagement } \\
\text { Index } \\
\text { (ENGAGE 4-8, 10, } \\
\text { 12-15, reverse } \\
\text { items corrected; } \\
\text { average across } 10 \text { ) }\end{array}$ & $\begin{array}{l}\text { Student Perception } \\
\text { of Learning Index } \\
\text { (LEARN 1, 3-8, } \\
\text { reverse corrected; } \\
\text { average of } 6 \text { items, } \\
5 \text { points each) }\end{array}$ & $\begin{array}{l}\text { Student Perception } \\
\text { Performance Index } \\
\text { (PERFORM 1-5, } \\
\text { reverse corrected; } \\
\text { average across } \\
\text { three items) }\end{array}$ & $\begin{array}{l}\text { Student's } \\
\text { expected grade } \\
\text { in the course: } \\
\% \text { expecting B or } \\
\text { better }\end{array}$ \\
\hline Total class & $5.38(1.59)$ & $3.29(0.85)$ & $3.58(0.81)$ & $3.53(0.76)$ & $36 \geq \mathrm{B}$ or better \\
\hline Treatment section & $5.49(4.68) * *$ & $3.34(0.73)$ & $3.63(0.80)$ & $3.52(0.79)$ & 43 \\
\hline Control section & $4.68(1.92)$ & $3.24(0.96)$ & $3.53(0.82)$ & $3.52(0.79)$ & 29 \\
\hline \multicolumn{6}{|l|}{ Focus divisions } \\
\hline $\begin{array}{l}\text { Incoming GPA } \\
2.50 \text { and above } \\
\text { Below } 2.50\end{array}$ & $\begin{array}{l}5.16(1.84) \\
4.69(1.77)\end{array}$ & $\begin{array}{l}3.31(7.77) \\
3.21(1.16)\end{array}$ & $\begin{array}{l}3.68(0.66) * * \\
3.14(1.22)\end{array}$ & $\begin{array}{l}3.58(0.69) \\
3.27(0.98)\end{array}$ & $\begin{array}{l}38 \\
29\end{array}$ \\
\hline $\begin{array}{l}\text { Gender } \\
\text { Female } \\
\text { Male }\end{array}$ & $\begin{array}{l}5.42(1.54) \\
5.34(1.74)\end{array}$ & $\begin{array}{l}3.39(0.73) \\
3.13(1.00)\end{array}$ & $\begin{array}{l}3.66(0.77) \\
3.42(0.86)\end{array}$ & $\begin{array}{l}3.54(0.66) \\
3.49(0.89)\end{array}$ & $\begin{array}{l}33 \\
45\end{array}$ \\
\hline $\begin{array}{l}\text { Self-identified } \\
\text { Hispanic } \\
\text { No } \\
\text { Yes }\end{array}$ & $\begin{array}{l}5.32(1.59) \\
5.43(1.64)\end{array}$ & $\begin{array}{l}3.13(0.74) * * \\
3.59(1.04)\end{array}$ & $\begin{array}{l}3.54(0.78) \\
3.59(0.91)\end{array}$ & $\begin{array}{l}3.51(0.71) \\
3.57(0.89)\end{array}$ & $\begin{array}{l}42 * * \\
26\end{array}$ \\
\hline $\begin{array}{l}\text { Pell Grant eligible } \\
\text { No } \\
\text { Yes }\end{array}$ & $\begin{array}{l}5.19(1.15) \\
5.25(1.63)\end{array}$ & $\begin{array}{l}3.69(0.63) * \\
3.24(0.90)\end{array}$ & $\begin{array}{l}3.76(0.76) \\
3.51(0.85)\end{array}$ & $\begin{array}{l}3.39(0.70) \\
3.53(0.78)\end{array}$ & $\begin{array}{l}33 \\
40\end{array}$ \\
\hline $\begin{array}{l}\text { Native English } \\
\text { speaker } \\
\text { No } \\
\text { Yes }\end{array}$ & $\begin{array}{l}5.25(1.65) \\
5.48(1.60)\end{array}$ & $\begin{array}{l}3.39(0.68) \\
3.27(0.91)\end{array}$ & $\begin{array}{l}3.78(0.46)^{*} \\
3.49(0.89)\end{array}$ & $\begin{array}{l}3.53(0.70) \\
3.52(0.80)\end{array}$ & $\begin{array}{l}44 \\
38\end{array}$ \\
\hline $\begin{array}{l}\text { Mother college } \\
\text { educated } \\
\text { No } \\
\text { Yes }\end{array}$ & $\begin{array}{l}5.26(1.48) \\
5.47(1.66)\end{array}$ & $\begin{array}{l}3.18(0.94) \\
3.38(0.76)\end{array}$ & $\begin{array}{l}3.53(0.90) \\
3.59(0.71)\end{array}$ & $\begin{array}{l}3.62(0.82) \\
3.37(0.68)\end{array}$ & $\begin{array}{l}32 \\
43\end{array}$ \\
\hline $\begin{array}{l}\text { Note: Means and } \mathrm{s} \\
* p<.10 . * * p<.0 \\
\text { Pearson } \chi^{2} \text { test (for } \\
* * * \text { external engag }\end{array}$ & $\begin{array}{l}\text { lard deviation } \\
\text { ing a two-side } \\
\text { right column) }\end{array}$ & $\begin{array}{l}\text { rted. } \\
\text { st with equal var }\end{array}$ & es not assume & all columns e & far right) or a \\
\hline
\end{tabular}

\section{Student Behavior and Perception Differences}

We were able to observe student behavior through class activities, websites, and survey items. Points earned on the module quizzes and Connect homework were virtually the same across treatment and control sections. We brought in additional data from the McGraw-Hill website, including the ungraded practice Learn Smart exercises and an overall engagement score; in both cases students in the treatment section took more advantage of the publisher homework website. 
This external source shows a significantly higher degree of engagement recorded in the treatment section (5.49 points vs. 4.68 points, $p=0.03$ ).

In Table 3 no significant differences appear in the behavior survey questions between the treatment and control sections (ENGAGE, LEARN, PERFORM). However, there are different behavior and perception differences across subgroups of students. Students coming into the class with higher grades tended to use the publisher website to a greater degree (as measured by the McGraw-Hill Engagement Index). The index was higher overall and for this subgroup in the treatment section $(p=0.08)$, for native English speakers $(p=0.07)$, as well as for Hispanics in the treatment section (vs. the control; $p=0.03$ ). The survey engagement question shows a somewhat different trend. The group without Pell Grants was more likely to express agreement with the survey engagement questions. When the students were grouped by ethnicity, Hispanic students were more likely to express agreement with the survey engagement questions. In a separate ANOVA analysis, we found a significant positive interaction effect between treatment and Hispanic ethnicity on the ENGAGE average index $(F=2.74, p=0.10)$. Question items mattered; for instance, to the engagement question "I was absorbed in the experience," $35 \%$ of the students chose the 4-5 (agree or strongly agree) on the Likert scale, with the highest positive responses by Hispanic students (43\%, compared to $28 \%$ for non-Hispanics, $\left.\chi^{2}(1)=8.63\right)$.

Table 3 also shows that those for whom English was not their first language expressed higher perceived learning. Almost $69 \%$ of the non-native English speakers answered agree or strongly agree on nearly all of the items (compared to $43.3 \%$ of the native speakers). The video presentations may have helped language learners since they could watch the media as many times as they wanted. However, when the students were considered along a different dimension (incoming GPA), those with lower grades tended to have lower perceived learning from the class and lower grade expectations. And non-Hispanics had higher grade expectations, since they more frequently stated their grades would be at the top end of the seven categories $(\mathrm{A}, \mathrm{A}-\mathrm{B}+, \mathrm{B}, \mathrm{B}-\mathrm{C}+$, $\mathrm{C}, \mathrm{C}-/ \mathrm{D}+, \mathrm{D})$. This differential for this subgroup was particularly strong in the treatment section, where $52 \%$ of the students expected a B or better, while only $29 \%$ expected this in the control section.

Additionally, open-ended questions were included in the second survey. The first question asked students in the treatment section to "describe if and how the learning activity (class video presentations) changed your engagement in this class." Most responses favored the activity, highlighted engagement/learning aspects of the activity, and confirmed the effect of peer learning. Some examples include the following:

"The class video presentation exercise changed my engagement in the class in a positive way it gave myself and other students accountability to interact by giving our personal feedback and explaining our problems."

"It was useful to better understand problems I couldn't solve on my own."

"The video presentations were pretty helpful in increasing engagement within the class. Creating the video really made you learn the subject, while watching others' videos made sure that I would keep tuning in every week."

However, there were still a few negative comments (five of the 48 participants). These negative comments could help design the activity better in the future: 
"I personally do not think it helps but only creates busy work in class and only is there to get points for participation."

"The videos did not fully change my engagement in class. Comments on the videos stimulated discussion but it was mostly surface level and one sided. I think most students posted their one comment for a grade rather than in-depth discussion. From all the assignments in this course, it was the one I thought about the least."

Students in the treatment section answered a second open-ended question: "Describe if and how the learning activity (class video presentations) changed your learning experience." Again, most responses were positive, with comments such as the following:

"The video presentation exercise changed my learning experience in this class in a positive way because before creating my video, I ensured I fully understood the concept so it was teachable and presented clear enough when it came to making my personal presentation."

"It changed my learning experience because online classes can be pretty limiting in participation, but this presentation was a great way to participate as well as learn from."

\section{Quantitative Student Learning Outcomes}

\begin{tabular}{|c|c|c|c|}
\hline \multicolumn{4}{|l|}{ Actual Learning (Quantitative Outcomes) } \\
\hline Students taking final & $\begin{array}{c}\text { Treatment } \\
(n=44)\end{array}$ & $\begin{array}{l}\text { Control } \\
(n=43)\end{array}$ & $p$-value \\
\hline Class GPA & $\begin{array}{c}2.55 \\
(0.82)\end{array}$ & $\begin{array}{c}2.31 \\
(0.78)\end{array}$ & .95 \\
\hline $\begin{array}{l}\text { Total class points ( } \% \text { of } 500 \text {; grades assigned } \\
\text { on } 50 \text { pts.) }\end{array}$ & $\begin{array}{l}74.10 \\
(19.37)\end{array}$ & $\begin{array}{c}72.43 \\
(19.70)\end{array}$ & .675 \\
\hline Pass rate $(0,1 ; 1$ if $\mathrm{C}$ or better $)$ & $72.9 \%$ & $67.3 \%$ & .55 \\
\hline Final exam word problems points $(0-30)$ & $\begin{array}{l}25.59 \\
(4.04)\end{array}$ & $\begin{array}{l}25.43 \\
(3.43)\end{array}$ & .842 \\
\hline Final exam multiple-choice points $(0-120)$ & $\begin{array}{c}65.97 \\
(14.59)\end{array}$ & $\begin{array}{c}61.28 \\
(13.69)\end{array}$ & .124 \\
\hline Pretest average $(0-10)$ & $\begin{array}{c}3.34 \\
(1.60)\end{array}$ & $\begin{array}{c}3.60 \\
(1.84) \\
\end{array}$ & .69 \\
\hline Posttest average $(0-10)^{*}$ & $\begin{array}{c}5.59 \\
(2.11)\end{array}$ & $\begin{array}{c}4.78 \\
(1.90)\end{array}$ & .067 \\
\hline $\begin{array}{l}\text { Value-added (post-pre)* } \\
\text { (range }-10 \text { to }+10)\end{array}$ & $\begin{array}{c}2.25 \\
(2.44)\end{array}$ & $\begin{array}{c}1.27 \\
(2.72)\end{array}$ & 0.083 \\
\hline \multicolumn{4}{|c|}{$\begin{array}{l}\text { Note: Means and standard deviations reported. } \\
* p<.10 .{ }^{*} p<.05 \text { using a two-sided } t \text {-test with equal variances not assumed (for all columns except } \\
\text { far right) or a Pearson } \chi^{2} \text { test (third row) }\end{array}$} \\
\hline
\end{tabular}

Table 4 provides data on the learning assessment from class grades and scores on the cumulative final exam. Students in the treatment section tended to earn more class points overall, receive a slightly higher grade, and passed the class more frequently, although the differences were not significant. However, students in the treatment section did perform significantly better on certain final 
exam multiple-choice items. Their learning on the key concepts (especially market equilibrium, elasticity, and market structure) included on the pretest and posttest did improve. This is to be expected since the student video work demonstrated how to solve such multiple-choice-type problems. There was a significant 1-point increase on the value-added scores of students in the treatment section.

We next turn to how different subgroups of students performed on the learning measures. Table 5 suggests that background factors matter on the student's final exam performance. When students were grouped along their previous grades, those with higher incoming GPAs were more likely to pass the class and earn a better grade. All final exam measures were higher for them. Hispanic students tended to earn lower grades and do somewhat worse on the final exam multiple-choice items. Being a native English language speaker provided a significant boost only on the written part of the final exam. In addition, when the students were divided by whether or not their mother completed college, we found that those without college-educated mothers tended to earn lower overall grades and perform worse on the multiple-choice items of the final exam. We also looked at learning gain through the difference between pre- and postquiz questions. Students who are not first generation scored 1.5 points higher on the value-added questions, particularly in the treatment section $(p=.07)$. We also observed that students with higher GPAs tended to have higher learning gains than students with lower incoming GPAs.

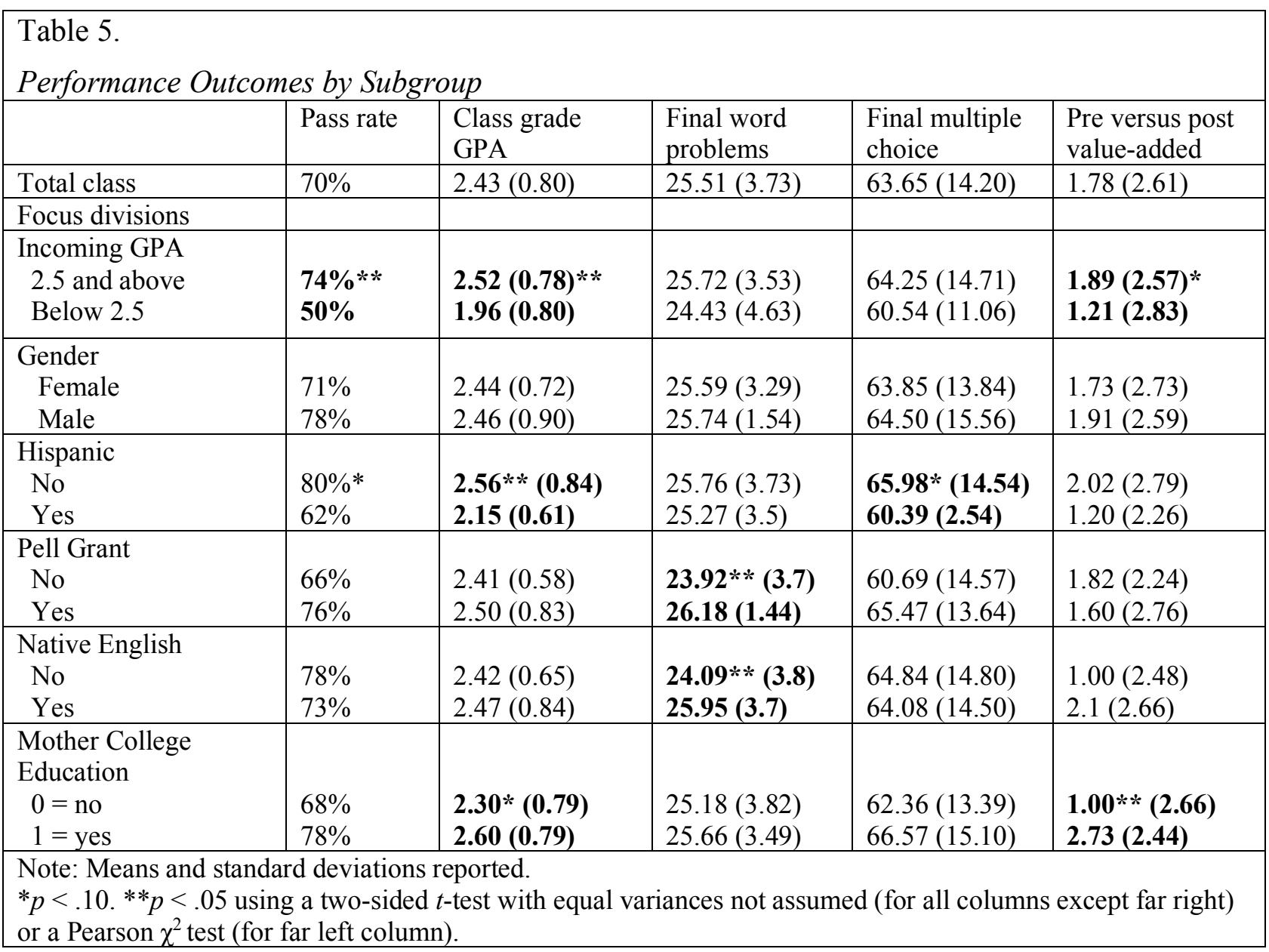


The question remains whether the video production activity could have changed how these background factors related to the actual learning outcomes. In separate subsample mean tests, a few significant differences appeared for the value-added learning outcome of the students of that group in the treatment section compared to the students of that group in the control section. For instance, students with higher incoming GPAs and non-Hispanic students did better in the treatment section than they did in the control group. In the univariate analysis of variance of Appendix C (Test of Between-Subjects Effects), there were no significant interaction effects between the treatment intervention and each specific subgroup characteristic. However, the treatment alone did explain a large part of the variation in student value-added scores across nonHispanic and native English language groups; their mean value-added scores were over 1 point higher in the treatment section (compared to the control) in both cases $(p=.08$ and $p=.09$, respectively).

\section{Discussion}

\section{Summary of Results and Connection to the Literature}

Student podcasting and video production can improve engagement and learning in online coursework. Here, we implemented a randomized experiment with upper division students enrolled in the same class, in sections with and without video production. By looking at class performance, we observed better class performance and learning gains in the treatment section when compared with the control section. This observation provides some support for our assumption that student-generated videos will increase engagement and learning.

Video production could have been a challenging activity for some groups. Those without technical skills or English as primary language could feel less prepared at the beginning of the semester; however, over time we observed that actual language-based learning gaps were reduced. Student academic preparation for the class (incoming GPA, meeting the prerequisites, etc.) remained crucial. But interestingly, on item-response questions, most students surveyed did not feel less prepared or lacking the necessary skills for the online course experience.

The main findings of this study are summarized below:

1. The students had diverse demographic and behavioral characteristics, particularly regarding their incoming GPA levels, gender, ethnicity, first-generation learner, Pell Grant status, and command of the English language. All subgroups of students participated in the treatment activity nearly equally. But each of these subgroups had somewhat similar selfexpressed beliefs in their online skill proficiency and self-directedness, as well as the efficacy of online learning. Like the student body analyzed in Hargittai (2010), we observed that better off students (i.e., without Pell Grants) had completed more online coursework and possessed higher perceived online skills. (And non-English native language students were concerned about their skills and had taken the smallest number of online courses.) We note that women expressed the greatest belief in the efficacy of (and enthusiasm for) online coursework, while those with college-educated mothers scored higher on the index of self-directedness.

2. Three engagement trends were examined: student work on the McGraw-Hill Connect website, student performance/effort on other class activities, and student responses to specific survey questions. Only in the first case did students in the treatment section 
demonstrate higher levels of engagement. Students in the two treatment groups did not behave significantly differently regarding participation in various class activities or on the survey-based questions. Qualitative comments suggest students generally enjoyed the activity, with some split over the value of viewing and rating other students' work. This does not follow some other studies of student podcasting (Anderson, 2013; Armstrong, Tucker, \& Massad, 2009; Moryl, 2016) in which very high student enthusiasm was noted. Our results are more similar to those of Bolliger and Armier (2013), with a strong majority of participants noting increased perceived learning. Among the other inherent background factors, better off students expressed the highest level of engagement with the overall course on the survey response measures; and the study here follows the trend noted in Zhang (2015) in which Hispanic students had higher agreement responses to particular questions around attention focus in the course.

3. Although there were few perceived differences in the performance and learning response questions, survey results show non-Hispanic and higher GPA students expecting to do well in the class. Qualitative comments implied that the experimental treatment students perceived that their learning had increased. In actuality, final grade assignment and actual learning were not much higher across treatment groups or subgroups. A small but significant treatment versus control difference was detected in the final posttest questions and value-added measures, particularly for higher GPA and/or non-Hispanic students. These gains are lower than those observed for the student podcasting work in marketing (Orus et al., 2016) and contrast the improvements for lower GPA students noted in Dupuis et al. (2013) for molecular biology. For our sample, the students' mothers' college education was most associated with actual learning achievements. There were no interaction effects between treatment group and student background factors.

Taken together, these findings suggest inherent background factors affect a student's trajectory through online learning preparation, specific assignments, processes, and outcomes. Our students with low incoming GPAs had taken fewer online courses previously, were less engaged in the course, had lower grade expectations in both sections, and ultimately achieved lower actual learning outcomes. A similar path was observed for the group of students whose mothers had not completed college. On the other hand, students with English as a native language expressed higher online experience but lower perceived learning than those without an English background; however, the native English speakers did better on some of the actual learning measures. These paths appeared across both class sections (with and without video production).

It is worth recalling that the student video production activity represented a small part of the overall grade and was done alongside other learning activities (whose effectiveness is not discussed here). We posit that the precise learning improvement from the activity comes down to enhanced mastery of specific concepts in the class, rather than overall learning of the material. To verify this, we further explored possible specialized learning from video production. The final exam included several word problems and 48 multiple-choice questions, with subgroups related to each learning module of the class. There were four questions for each of the modules related to early content (overview, supply and demand, elasticity, production and cost, incentives, and market structure measures), and eight questions per module for the new areas not covered on the earlier midterms (perfect competition/monopoly, oligopoly, and advanced pricing strategies). The module/chapter for which each student produced a video was identified, without those modulespecific questions removed from the "overall learning" group. So, for instance, students who 
produced a problem-solving video on the Chapter 3 material would have their scores on the total four questions related to Chapter 3 compared to the remaining questions (44 possible questions). We compared the proportion of each student's correct "material-related" questions to the overall question material. Generally, $62 \%$ of the students did better on the questions related to their activity content, compared to the overall questions included on the final exam (average 52\% correct) $(t=$ $1.88 ; p=.16$ ). Yet this pattern was clearest on the review material earlier in the semester, compared to the more advanced sections later in the semester.

\section{Limitations}

The research design focused on the incremental (marginal) impact of a new activity, with all other aspects of the course design in place. The comparison courses were designed to provide moderate incentives for participating in the new video activity while maintaining the integrity of the other course components and exam assessment measures across both the control and treatment sections. Very small (marginal) impacts were determined. If the student-generated assignment had represented a larger part of the class (e.g., each student producing three videos for $30 \%$ of the grade), we would expect to have seen larger learning gains.

And the analysis is based on a small sample size and only on included multiple-choicetype items for problem-solving skills. An exercise in which a larger number of students produced videos to address case study or essay-type questions may provide different results. Finally, the experiment took place in the context of students' (and the instructor's) learning curve on the assignment and video production process. If students participated in the same activity in a subsequent course (such as a major capstone), different learning gains could perhaps be observed.

\section{Future Research Directions}

Here we explored the association between the video intervention activity in the class and student learning outcomes. We discussed how this association could vary across different student subgroup variations, which could serve as both controls and drivers in the process. Future research should explore the direct and indirect causation between student background factors, class interventions, and learning outcomes. That is, a path analysis approach could link student background factors (indirectly) to exam scores and performance through the measures of engagement and perceived learning/performance. Additionally, two-stage regression analysis would treat the processes sequentially.

\section{Acknowledgements}

Funding was provided by the National Research Center for Distance Education and Technological Advancements (DETA) (Subaward \#163405512) and the U.S. Department of Education Fund for the Improvement of Postsecondary Education. We are thankful for the instructional support from Morassa Danai and the efforts of Ken Moyer and Susan Gaitan in the design of Titanium (Moodle) website activities for this project. The research and administrative assistance of Elizabeth Pontius, Ka Yi, and Marisol Cardenas are also appreciated. 


\section{References}

Alon, I., \& Herath, R. (2014). Teaching international business via social media projects. Journal of Teaching in International Business, 25, 44-59.

Alpay, E., \& Gulati, S. (2010). Student-led podcasting for engineering education. European Journal of Engineering Education, 35, 415-427.

Armstrong, G., Tucker, J., \& Massad, V. (2009). Achieving learning goals with student-created podcasts. Decision Sciences Journal of Innovative Education, 7, 149-154.

Betts, K., Hartman, K., \& Oxholm, C. (2009). Re-examining \& repositioning higher education: Twenty economic and demographic factors driving online and blended program enrollments. Journal of Asynchronous Learning Networks, 13(4).

Bolliger, D., \& Armier, D., Jr. (2013). Active learning in the online environment: The integration of student-generated audio files. Active Learning in Higher Education, 14, 201-211.

Bolliger, D., Supanakorn, S., \& Boggs, C. (2010). Impact of podcasting on student motivation in the online learning environment. Computers and Education, 55, 714-722.

Carr, S. (2000). As distance education comes of age, the challenge is to keep the students. The Chronicle of Higher Education, 46(23), A39-41.

Chang, S., \& Smith, R. (2008). Effectiveness of personal interaction in a learner-centered paradigm distance education class based on student satisfaction. Journal of Research on Technology in Education, 40, 407-426.

Clark, K. (2009, April 2). Online education offers access and affordability. US News and World Report. Retrieved from https://www.usnews.com/education/onlineeducation/articles/2009/04/02/online-education-offers-access-and-affordability

Dixson, M. (2010). Creating effective student engagement in online courses: What do students find engaging? Journal of the Scholarship of Teaching and Learning, 10, 1-13.

Dupange, M., Millette, D., \& Grinfeder, K. (2009, Spring). Effectiveness of video podcast use as a revision tool. Journalism and Mass Communication Educator, 54-70.

Dupuis, J., Coutu, J., \& Laneuville, O. (2013). Application of linear mixed-effect models for the analysis of exam scores: Online video associated with higher scores for undergraduate students with lower grades. Computers and Education, 66, 64-73.

Fulk, J., Schmitz, J., \& Steinfield, C. (1990). A social influence model of technology use. In J. Fulk \& C. Steinfield (Eds.) Organizations and communication technology (pp. 117-140). Newbury Park, CA: Sage.

Guertin, L. (2010). Creating and using podcasts across the disciplines. Currents in Teaching and Learning, 2, 4-12.

Hargittai, E. (2010). Digital na(t)ives? Variation in Internet skills and uses among members of the "net generation." Sociological Inquiry, 80, 92-113.

Jan, S. (2015, March). The relationships between academic self-efficacy, computer self-efficacy, prior experience and satisfaction with online learning. American Journal of Distance Education, 30-40. 
Joosten, T., \& Reddy, D. (2015, October 1). Distance education and technological advancements research toolkit. National Research Center for Distance Education and Technological Advancements (DETA). Retrieved from http://uwm.edu/deta/toolkits/

Kay, R. (2012). Exploring the use of video podcasts in education: A comprehensive review of the literature. Computers in Human Behavior, 28, 820-831.

Lorenzo, G., \& Moore, J. (2002). The Sloan Consortium report to the nation: Five pillars of quality education. Retrieved from http://www.edtechpolicy.org/ArchivedWebsites/Articles/FivePillarsOnlineEducation.pdf

Moryl, R. (2013). T-shirts, moonshine, and autopsies: Using podcasts to engage undergraduate microeconomics students. International Review of Economics Education, 13, 67-74.

Moryl, R. (2016). Pod learning: Student groups create podcasts to achieve economics learning goals. The Journal of Economic Education, 47, 64-70.

National Survey of Student Engagement. (2010). Benchmarks of effective educational practice. NSSE: Indiana University School of Education. Retrieved from http://nsse.indiana.edu/pdf/nsse benchmarks.pdf

Orus, C., Barles, M., Belanche, D., Casalo, L., Fraj, E., \& Gurrea, R. (2016). The effects of learner-generated videos for YouTube on learning outcomes and satisfaction. Computers and Education, 95, 254-269.

Puzziferro, M. (2008, May). Online technologies self-efficacy and self-regulated learning as predictors of final grade and satisfaction in college-level online courses. American Journal of Distance Education, 72-89.

Rovai, A. (2000). Building and sustaining community in asynchronous learning networks. The Internet and Higher Education, 3, 285-297.

Zhang, M. (2015). Internet use that reproduces educational inequalities: Evidence from big data. Computers and Education, 86, 212-223.

Zhu, E. (2006). Interaction and cognitive engagement: An analysis of four asynchronous online discussions. Instructional Science, 34, 451-480. 


\section{Appendix A: Background Institutional Data}

\begin{tabular}{|l|c|c|}
\hline \multicolumn{2}{|c|}{ Beginning of semester background characteristics of treatment-control groups, spring 2016} \\
\hline & $\begin{array}{c}\text { Treatment } \\
(n=56)\end{array}$ & $\begin{array}{c}\text { Control } \\
(n=57)\end{array}$ \\
\hline Enrolled credits & 13.80 & 12.62 \\
& $(3.30)$ & $(3.07)$ \\
\hline Incoming GPA & 2.59 & 2.66 \\
& $(0.59)$ & $(0.59)$ \\
\hline Low incoming GPA & & $41 \%$ \\
(=1 if below median 2.50) & $54 \%$ & 2.83 \\
\hline Grade points ECON 201 & 2.75 & $(0.77)$ \\
& $(0.69)$ & 2.69 \\
\hline Grade points Math 135 & 2.63 & $(1.02)$ \\
\multicolumn{2}{|c|}{$(0.93)$} & 0.83 \\
Met prerequisites & 0.88 & $(0.38)$ \\
(1 = yes) & $(0.33)$ & \\
\hline Note. Means and standard deviations reported & \\
\hline
\end{tabular}




\section{Appendix B: Variables Definitions}

\begin{tabular}{|c|c|c|c|}
\hline Variable ID & Definition & Item & Coding \\
\hline Gender & $\begin{array}{l}\text { Student-reported } \\
\text { gender }\end{array}$ & $\begin{array}{l}\text { With which gender do you } \\
\text { identify? }\end{array}$ & $\begin{array}{l}1=\text { Male } \\
0=\text { Female }(\text { recoded }) \\
99=\text { Unknown }\end{array}$ \\
\hline Age of student & $\begin{array}{l}\text { Student self-reported } \\
\text { years of age }\end{array}$ & How old are you? & Continuous in years \\
\hline Ethnicity & $\begin{array}{l}\text { Student-reported } \\
\text { ethnicity }\end{array}$ & Do you identify as Hispanic? & $\begin{array}{l}0=\text { Non-Hispanic } \\
1=\text { Hispanic } \\
99=\text { Unknown }\end{array}$ \\
\hline \multirow[t]{2}{*}{\begin{tabular}{|l} 
First \\
generation
\end{tabular}} & $\begin{array}{l}\text { Student report of } \\
\text { mother's highest level of } \\
\text { education achieved }\end{array}$ & $\begin{array}{l}\text { What was the highest school } \\
\text { completed by your mother or } \\
\text { parent } 1 \text { ? }\end{array}$ & $\begin{array}{l}1=\text { Middle school/jr. high } \\
2=\text { High school } \\
3=\text { College or beyond } \\
99=\text { Other/unknown }\end{array}$ \\
\hline & $\begin{array}{l}\text { Student report of father's } \\
\text { highest level of } \\
\text { education achieved }\end{array}$ & $\begin{array}{l}\text { What was the highest school } \\
\text { completed by your father or } \\
\text { parent } 2 \text { ? }\end{array}$ & $\begin{array}{l}1=\text { Middle school/jr. high } \\
2=\text { High school } \\
3=\text { College or beyond } \\
99=\text { Other/unknown }\end{array}$ \\
\hline $\begin{array}{l}\text { Pell Grant } \\
\text { eligible }\end{array}$ & $\begin{array}{l}\text { Student's report of } \\
\text { eligibility }\end{array}$ & $\begin{array}{l}\text { Are you eligible or have you } \\
\text { received a Pell Grant? }\end{array}$ & $\begin{array}{l}\text { Yes }=1 \\
\text { No }=0 \text { (recoded }) \\
\text { Unknown }=99\end{array}$ \\
\hline \multirow[t]{2}{*}{$\begin{array}{l}\text { Time } \\
\text { commitment }\end{array}$} & $\begin{array}{l}\text { Self-reported paid hours } \\
\text { worked/week }\end{array}$ & $\begin{array}{l}\text { How many hours do you work per } \\
\text { week on average? }\end{array}$ & $\begin{array}{l}\text { Continuous (hours worked last } \\
\text { week), don't know, or none }\end{array}$ \\
\hline & $\begin{array}{l}\text { Self-reported number of } \\
\text { credit hours in past }\end{array}$ & $\begin{array}{l}\text { How many credits did you take } \\
\text { last semester? }\end{array}$ & $\begin{array}{l}\text { Continuous (number of credits } \\
\text { enrolled last semester) or don't } \\
\text { know }\end{array}$ \\
\hline $\begin{array}{l}\text { Native English } \\
\text { speaker }\end{array}$ & $\begin{array}{l}\text { Self-reported as English } \\
\text { as student's first } \\
\text { language }\end{array}$ & Is English your first language? & $\begin{array}{l}1=\text { Yes } \\
0=\text { No }(\text { recoded })\end{array}$ \\
\hline $\begin{array}{l}\text { Preparedness } \\
\text { and readiness }\end{array}$ & $\begin{array}{l}\text { Student's self-reported } \\
\text { experience in distance } \\
\text { education }\end{array}$ & $\begin{array}{l}\text { How many previous online } \\
\text { courses have you taken? }\end{array}$ & Continuous (number courses) \\
\hline
\end{tabular}




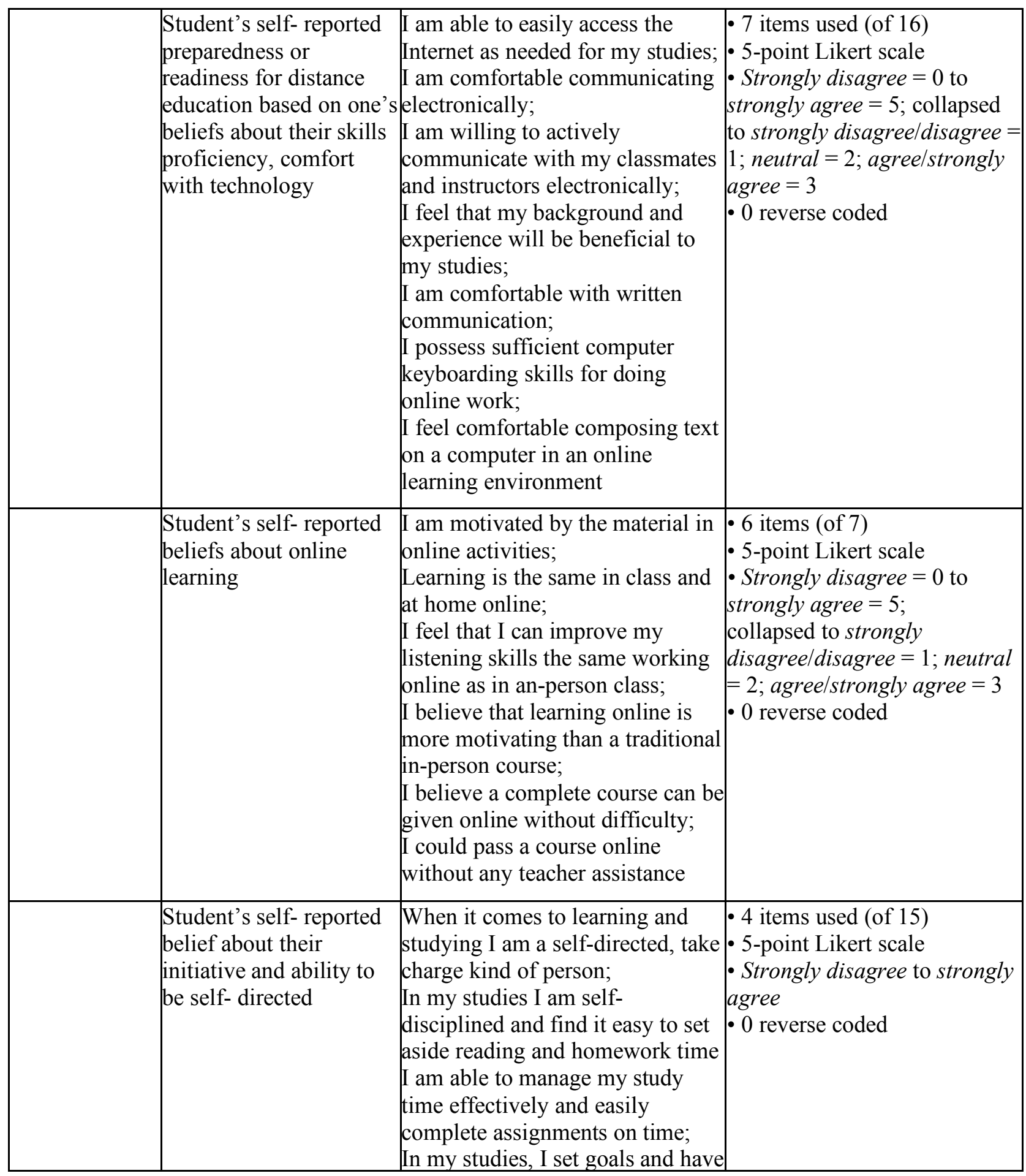




\begin{tabular}{|c|c|c|c|}
\hline Engagement & $\begin{array}{l}\text { Self-reported } \\
\text { engagement with } \\
\text { academic challenges, } \\
\text { active/collaborative } \\
\text { activities, } \\
\text { and course community }\end{array}$ & $\begin{array}{l}\text { I was captivated; } \\
\text { I felt wrapped up in the } \\
\text { experience; } \\
\text { I was absorbed in the experience; } \\
\text { I was attracted to the learning } \\
\text { activities; } \\
\text { The class was an enriching } \\
\text { experience; } \\
\text { Class was fun and exciting; } \\
\text { The class kept me totally } \\
\text { absorbed in the activity; } \\
\text { The class held my attention; } \\
\text { The class excited my curiosity; } \\
\text { The class aroused my imagination }\end{array}$ & $\begin{array}{l}-10 \text { items used (of } 21 \text { ) } \\
\text { - 5-point Likert scale } \\
\text { - Strongly disagree to strongly } \\
\text { agree } \\
\text { - None reverse coded }\end{array}$ \\
\hline Learning & $\begin{array}{l}\text { Student's self- reported } \\
\text { perceptions of learning }\end{array}$ & $\begin{array}{l}\text { The class allowed me to better } \\
\text { understand concepts; } \\
\text { The class helped me understand } \\
\text { the course material; } \\
\text { The class made it easy to connect } \\
\text { ideas together; } \\
\text { The class helped me think more } \\
\text { deeply about course material; } \\
\text { The class did not help my } \\
\text { learning; } \\
\text { The class did not make it easier } \\
\text { for me to understand the course } \\
\text { material; } \\
\text { I was not able to better understand } \\
\text { course concepts }\end{array}$ & $\begin{array}{l}\text { - } 6 \text { items used (of 10) } \\
\text { - 5-point Likert scale } \\
\text { - Strongly disagree to strongly } \\
\text { agree } \\
\text { - Some reverse coded }\end{array}$ \\
\hline Performance & $\begin{array}{l}\text { Student's self- reported } \\
\text { perceptions of } \\
\text { performance on } \\
\text { assessments and overall } \\
\text { in course }\end{array}$ & $\begin{array}{l}\text { The class activities helped me get } \\
\text { a better grade; } \\
\text { My experience in the course } \\
\text { helped me do better on my exams } \\
\text { and other assignments; } \\
\text { The class activities did not help } \\
\text { me score higher on the exams; } \\
\text { I got higher scores on my } \\
\text { assignments because of my } \\
\text { experience in the course; } \\
\text { The class activities did not } \\
\text { improve my assignment grades }\end{array}$ & $\begin{array}{l}\text { - } 5 \text { items } \\
\text { - 5-point Likert scale } \\
\text { - Strongly disagree to strongly } \\
\text { agree } \\
\text { - Some reverse coded }\end{array}$ \\
\hline Beliefs & $\begin{array}{l}\text { Student's self- reported } \\
\text { belief of their grade } \\
\text { earned }\end{array}$ & $\begin{array}{l}\text { What final grade do you expect to } \\
\text { receive in this class? }\end{array}$ & $\begin{array}{l}1=\mathrm{A} ; 2=\mathrm{A}-/ \mathrm{B}+; \\
3=\mathrm{B} ; 4=\mathrm{B}-/ \mathrm{C}+; 5 \\
=\mathrm{C} ; 6=\mathrm{C}-/ \mathrm{D}=; 7 \\
=\mathrm{D} ; 8=\mathrm{D}-/ \mathrm{F}+; 9=\mathrm{F} \\
99=\text { Don't know }\end{array}$ \\
\hline
\end{tabular}


Student-Produced Videos Can Enhance Engagement and Learning in the Online Environment

\begin{tabular}{|l|l|l|l|}
\hline Video engage & $\begin{array}{l}\text { Treatment student } \\
\text { response }\end{array}$ & $\begin{array}{l}\text { Describe if and how the learning } \\
\text { activity (class video presentation) } \\
\text { changed your engagement. }\end{array}$ & Open-ended question \\
\hline Video learn & $\begin{array}{l}\text { Treatment student } \\
\text { response }\end{array}$ & $\begin{array}{l}\text { Describe if and how the learning } \\
\text { activity (class video presentation) } \\
\text { changed your learning experience. }\end{array}$ & Open-ended question \\
\hline $\begin{array}{l}\text { Final exam } \\
\text { score }\end{array}$ & $\begin{array}{l}\text { Total points on final } \\
\text { exam }\end{array}$ & Instructor data & $\begin{array}{l}\text { Numeric continuous on scale } \\
\text { of 100 or 150 points per class }\end{array}$ \\
\hline $\begin{array}{l}\text { Multiple-choice } \\
\text { questions }\end{array}$ & $\begin{array}{l}\text { Total correct multiple- } \\
\text { choice questions in class }\end{array}$ & Instructor data & $\begin{array}{l}\text { Numeric continuous on a scale } \\
\text { of 48-50 per class }\end{array}$ \\
\hline $\begin{array}{l}\text { Posttest } \\
\text { questions } \\
\text { correct }\end{array}$ & $\begin{array}{l}\text { Total correct answers on } \\
\text { selected 10 pre- and } \\
\text { posttest questions }\end{array}$ & $\begin{array}{l}\text { Instructor data } \\
\text { Numeric continuous on a 0-10 } \\
\text { scale }\end{array}$ & $\begin{array}{l}\text { Numeric continuous on a } \\
\text { scale of -10 to 10 }\end{array}$ \\
\hline $\begin{array}{l}\text { Value-added } \\
\text { difference pre- } \\
\text { and posttest } \\
\text { questions }\end{array}$ & $\begin{array}{l}\text { Difference between } \\
\text { number of correct } \\
\text { questions when same } \\
\text { questions done in pretest } \\
\text { and in posttest }\end{array}$ & Instructor data & \\
\hline
\end{tabular}


Appendix C: Significance and Interaction of Treatment and Subgroup Characteristics on Value-Added Scores From Pretest and (Final) Posttest Questions

\begin{tabular}{|l|l|l|l|l|}
\hline Variable/group & Type III SOS & $\begin{array}{l}\text { Degrees of } \\
\text { freedom }\end{array}$ & $F$-statistic & $p$-value \\
\hline Low incoming GPA & & & & \\
\hline Treatment & 19.09 & 1 & 11.09 & .19 \\
Low GPA & 13.48 & 1 & 7.83 & .22 \\
Interaction & 1.72 & 1 & 0.26 & .61 \\
\hline Gender & & & & \\
\hline Treatment & 18.45 & 1 & 29.90 & .12 \\
Gender & 0.72 & 1 & 1.17 & .48 \\
Interaction & 0.62 & 1 & 0.09 & .77 \\
\hline Hispanic & & & & \\
\hline Treatment & 11.07 & 1 & 2.85 & .34 \\
Hispanic & 7.63 & 1 & 1.97 & .40 \\
Interaction & 3.88 & 1 & 0.57 & .45 \\
\hline Pell Grant eligible (PGE) & & & & \\
\hline Treatment & 8.24 & 1 & 16.13 & .16 \\
PGE & 0.39 & 1 & 0.77 & .54 \\
Interaction & 0.51 & 1 & 0.07 & .79 \\
\hline Mother's education & & & & \\
\hline Treatment & 3.24 & 1 & 0.70 & .41 \\
Mother's education & 49.92 & 2 & 9.73 & .09 \\
Interaction & 5.13 & 2 & 0.39 & .68 \\
\hline Native English speaker & & 1 & & .02 \\
\hline Treatment & 7.81 & 1 & 905.46 & .92 \\
\hline English & 12.63 & & 0.001 & .97 \\
Interaction & 0.01 & &
\end{tabular}

